\title{
PROLONGING THE SUNDAY CLOSING IMBROGLIO: REGINA V. VIDEOFLICKS LTD.
}

IVAN F. IVANKOVICH

\section{INTRODUCTION}

National attention was recently focused upon the decision of the Supreme Court of Canada in R. v. Big M Drug Mart Ltd. ${ }^{1}$ The court held that the Lord's Day $\mathrm{Act}^{2}$ was validly enacted pursuant to the federal criminal law power under s. 91(27) of the Constitution Act, 1867 but that it was nevertheless unconstitutional because it infringed the right to freedom of conscience and religion in section 2(a) of the Charter of Rights and Freedoms and the infringment could not be justified under $s$. 1 of the Charter. The decision left open for subsequent consideration the precise parameters of provincial legislative authority in the area of uniform closing laws. The Supreme Court shall, in the near future, have that opportunity when it considers four appeals arising from the case of $R$. v. Videoflicks Ltd. et. al. ${ }^{3}$ This unanimous decision of the Ontario Court of Appeal, handed down seven months prior to the S.C.C. decision in Big $M$, is noteworthy for upholding the constitutional authority of the provinces to enact Sunday closing legislation while, at the same time, abregating its general effectiveness by judicially imposing a stratification based upon freedom of religion which enables an individual or group of individuals to remain outside of the general legislative provisions affecting other individuals or groups. If this approach prevails in the Supreme Court of Canada, provincial legislatures will be unable to enact effective Sunday closing laws without the assistance of an express declaration under s. 33 of the Charter. ${ }^{4}$

\section{VIDEOFLICKS IN THE COURT OF APPEAL}

In $R$. v. Videoflicks Ltd. et. al. the Ontario Court of Appeal dealt with appeals from the following eight decisions of provincial of fences appeal courts: $R$. v. Videoflicks Ltd, R. v. Nortown Foods Ltd., R. v. Chaimovitz, $R$. v. Longo Bros. Fruit Markets Ltd., R. v. Commisso, $R$. v. Magder (No. 3), R. v. Edwards Books \& Art Ltd., and R. v. Creative Sportswear Co. Ltd. In each case the appellant was convicted of carrying on a retail business or of fering goods or services for sale on a Sunday

- Of the Faculty of Business, University of Alberta, Edmonton.

1. (1985) 58 N.R. 81 . Hereinafter the case may be referred to as Big $M$.

2. R.S.C. 1970 , c. L-13.

3. (1985) 48 O.R. (2d) 395 (Ont. C.A.) Leave to appeal to the Supreme Court of Canada granted in respect of Magder v. The Queen, Edward Books and Art Lid. v. The Queen, Longo Brothers Fruit Markets Ltd. v. The Queen, and R. v. Nortown Foods Ltd. (Estey, McIntyre, and Wilson JJ.) May 10, 1985. Hereinafter the Ontario Court of Appeal decision may be referred to as Videoflicks.

4. The non-obstante or "opting-out" clause provides a time-limited legislative override for some of the central rights and freedoms guaranteed by the Charter including the right to freedom of conscience and religion. 
contrary to s. 2(1) of Ontario's Retail Business Holidays Act, ${ }^{5}$ which provides as follows: 6

2(1) Every person carrying on a retail business establishment shall ensure that no number of the public is admitted thereto and no goods or services are sold or offered for sale therein by retail on a holiday.

While two of the appeals were allowed on narrow grounds, ${ }^{7}$ the other six appeals required the Ontario C.A. to address two constitutional issues: (1) whether the Retail Business Holidays Act is within the legislative jurisdiction of the Province of Ontario, and (2) whether s. 2 of the Act is inconsistent with the Canadian Charter of Rights and Freedoms and, if so, the extent of the inconsistency.

The Ontario Court of Appeal, relying on two recent cases from the Manitoba Court of Appeal and the British Columbia Supreme Court, upheld provincial legislation jurisdiction. ${ }^{8}$ According to these authorities, where the main purpose of impugned uniform closing legislation is secular (i.e., to regulate shopping hours and/or to provide holidays for some persons engaged in certain retail trades) as opposed to religious (i.e., to prevent profanation of the Sabbath), it can be supported as a valid exercise of provincial legislative authority notwithstanding the fact that Sundays and some other days of a religious significance are included in the definition of "holiday."

After concluding that the Retail Business Holidays Act met this test, the court directed its attention to whether s. 2 of the Act, having an intra vires purpose from the standpoint of legislative jurisdiction, could still be held to infringe the Charter because of its "effect"'. In this respect it is important to note that in five of the six appeals decided on this issue the appellants were unable to raise any "actual" infringements of their respective freedoms of religion. These appellants sought to have the Act declared of no force or effect on the basis of its general infringement of the religious freedom guaranteed by s. 2(a) of the Charter. In the case of Nortown Foods Ltd., however, an "actual" infringement was alleged. The appellant corporation operated a food store. The corporation itself was owned by two shareholders who were Orthodox Jews and, in accordance with the tenets of their religious faith, the food store was not open for business on Saturdays. The appellant corporation argued that the Retail Business Holidays Act actually infringed upon its freedom of

S. R.S.O. 1980 , c. 453

6. According to s.1(1)(a) of the Act "holiday" is defined to mean, inter alia, (j) New Ycar's Day, (ii) Good Friday, (iii) Victoria Day, (iv) Dominion Day, (v) Labour Day, (vi) Thanksgiving Day, (vii) Christmas Day, (viii) Boxing Day, and (ix) Sunday. While s.3 of the Act contains certain exemptions from the application of s.2(1), these are not afforded on religious grounds per se.

7. The court concluded that the appellant Videoflicks Ltd., in renting videotapes on Sunday, was not engaging in a service which was "sold" or "offered for sale . . by retail" within the meaning of s.2(1): supra, n. 3 at 433-437, and that the appellant Chaimovitz, in selling goods from a makeshift stall at a Sunday "flea-market," was not "carrying on a retail business establishment" within the meaning of s.2(1): id., at 437-439.

8. In R. v. Tamarac Foods Ltd. (1978) 96 D.L.R. (3d) 678, the Manitoba Court of Appeal upheld the validity of the Retail Business Holiday Closing Act, S.M. 1977, c. 26. In R. v. Duncan Supermarket Ltd. (1982), 135 D.L.R. (3d) 700, the British Columbia Supreme Court upheld the validity of the Holiday Shopping Regulation Act, S.B.C. 1980, c. 17. 
religion by imposing an economic sanction for its observance of a sabbath on a day other than Sunday, i.e., lost profit in having to close its store on two days a week. ${ }^{9}$

In formulating the parameters of religious freedom under the Charter the Ontario Court of Appeal departed completely from the similar and restrictive definitions of religious freedom historically advanced by the Supreme Courts of the United States and Canada. The test adopted in 1961 by the American Supreme Court to determine if a statute violates constitutional guarantees of religious freedom in these circumstances is whether a "direct" as opposed to "indirect" burden is imposed upon the free exercise of religion. ${ }^{10}$ Two years later the Supreme Court of Canada applied much the same approach in upholding the validity of Sunday closing laws challenged under the Canadian Bill of Rights. Mr. Justice Ritchie, delivering the majority judgment of the court in Robertson and Rosetanniv. The Queen defined freedom of religion as being the right to hold religious beliefs without coercion or restraint and the right to profess those beliefs openly and concluded that a dissentient's right to freedom of religion under the Bill of Rights was not infringed solely by the mere economic effect of having to close on two days a week rather than one. 11

In Videoflicks the Ontario Court of Appeal, in a prescient analysis, negatived the applicability of the direct-indirect test. After distinguishing the American and Canadian precedents, ${ }^{12}$ Tarnopolsky, J.A., in delivering the unanimous judgment of the court, stated: "The reference [to freedom of conscience and religion in the Charter] is not to the past but to the present as interpreted now and in the future." 13 Without attempting definition, he then proceeded to frame a broad interpretation of religious freedom consistent with Canada's international obligations ${ }^{14}$ and the principle of cultural pluralism recognized in s. 27 of the

9. Alternatively the store would have had to be operated with a reduced work force and square footage on Sundays in order to bring it within the exception in s.3(4) of the Act, thus still constituting an indirect economic sanction.

10. Thus the validity of state Sunday closing laws has been upheld in the United States on the basis that such laws imposed only an "indirect" burden upon Orthodox Jewish retailers whose faith required them to rest on Saturdays: Braunfeld v. Brown (1961), 366 U.S. 599; Gallagherv. Crown Kosher Super Market (1961) 366 U.S. 617.

11. [1963] S.C.R. 651 at 657-658.

12. The American precedents were distinguished on the ground that, unlike the Charter, the U.S. Constitution provided neither an internal limitations clause nor an entrenched principle of pluralistic cultural preservation and enhancement: supra, n. 3 at 424-426. The Canadian precedent was distinguished on the ground that, unlike the Charter, the Canadian Bill of Rights was only declaratory of the rights in existence at the time of its enactment: $i d$., at 417-419. This correctly presaged a rejection on similar grounds by the S.C.C. in Big M: supra, $\mathrm{n} .1$ at $110-112$.

13. Supra, n. 3 at 419.

14. Tarnopolsky, J.A. noted that Article 18 of the International Covenant on Civil and Political Rights, G.A. Res. 2200 A, 21 U.N. GAOR., Supp. No. 16, U.N. Doc. AS-6316 (1966), provides that the right to freedom of religion expressly includes not only the right to have a religion of one's choice, but also the right "to manifest [that] religion or belief in worship, observance, practice and teaching"': supra, n. 3 at $420-421$. Later in his judgment he notes that Article 27 prohibits denying to minorities the right, inter alia, "to profess and practice their own religion"': id., at 427. (Emphasis added.) 
Charter, ${ }^{15}$ noting that religious practices can be manifested by a multiplicity of human activity or inactivity than non-observers might categorize as exclusively secular. ${ }^{16}$ Notwithstanding the virtual failure of the Retail Business Holidays Act to accommodate religious freedom under these broadly defined parameters, the Ontario Court of Appeal refused to declare its operative provisions of no force or effect. Instead, it upheld the constitutional validity of the Act but under the Charter declared its operative provisions inapplicable on a selective basis. According to the court, the Act, by making observance of a non-Sunday sabbath financially onerous, does not infringe upon religious freedom per se but only upon the religious freedom of those who "sincerely" observe a day other than Sunday as their sabbath. ${ }^{17}$ Applying this test, only the appellant Nortown Foods Ltd. had established the prerequisite actual infringement. All that remained in the court's view for consideration, therefore, was whether, vis-a-vis that appellant, the infringement contemplated by s. 2 of the Retail Business Holidays Act was a reasonable limitation within s. 1 of the Charter and the court summarily dismissed that possibility on the ground that "[no] evidence was submitted concerning inconveniences that might result from permitting Sabbatarian exemptions." 18

\section{COMMENTARY}

Concerns raised elsewhere ${ }^{19}$ about the practical consequences of the Videoflicks decision and the cavalier attitude adopted by the Ontario Court of Appeal in considering these consequences are largely unfounded. It is true that, in order to prevent unscrupulous retailers from forming or joining religious groups which observe as their sabbath the day of the week on which business is slowest, the decision requires judiciallyconducted inquiries into the "sincerity" of an individual's religious belief. But courts are certainly not unaccustomed to conducting such inquiries for other purposes ${ }^{20}$ and the factors relevant to an assessment of the "sincerity" of religious belief have previously been enumerated. ${ }^{21}$ As well, judicially-conducted inquiries may be better equipped to provide a genuine assessment than definitive standards arbitrarily imposed by the legislature. ${ }^{22}$

15. S. 27 provides: "This Charter shall be interpreted in a manner consistent with the preservation and enhancement of the multicultural heritage of Canadians."

16. See Videoflicks, supra, n. 3 at $\mathbf{4 2 1}$.

17. In order to claim an exemption on religious grounds it was the court's view that "... one must be prepared to show that the objection is based upon a sincerely held belief based upon a lifestyle required by one's conscience or religion': id., at 423.

18. Id., at 429.

19. See Ontario Lawyers Weekly 4 no. 21 (April 5, 1985): 5 and Ontario Lawyers Weekly 5 no. 1 (May 3, 1985): 5.

20. As pointed out by the Ont. C.A., inquiries into the sincerity of religious belief are mandated under labour relations legislation with respect to conscientious objection to trade union nembership.

21. See Re Civil Service Association of Ontario (Inc.) v. Anderson (1975), 60 D.L.R. (3d) 397, 399. (Ont. Div. Ct.).

22. Cf. Shops Act, 1950 (U.K.), 14 Geo. 6 c. 28, s. 53. 
A valid criticism can be made with respect to the Ontario C.A.'s failure to expressly disclose its rationale for deciding that the Charter guarantee of freedom of religion is applicable to corporations. But cogent reasons have been elsewhere advanced to support that proposition ${ }^{23}$ and, assuming its validity, the religious beliefs of Nortown Foods Ltd. and its shareholders were quite properly treated as indistinguishable by the court for the simple reason that the store in question was owned by two shareholders who were both Orthodox Jews. Cases inevitably will arise presenting more complex considerations but it is suggested that, in the absence of a legislative standard, ${ }^{24}$ a common sense rule such as making the application of the exemption in such circumstances dependent upon the genuine religious beliefs of a majority of the directors would prove entirely satisfactory.

The substantive issues raised by Videoflicks are much broader in scope, viz. (1) whether Ontario or any province, in pursuit of a valid secular objective, can justify uniform closing legislation without substantial religious exemptions as a "reasonable limit" upon the religious freedom guaranteed by the Charter, and (2) if not, what effect does the failure to provide substantial religious exemptions have upon extant legislation. The detailed commentary which follows is directed to these aspects of the Videoflicks case.

\section{A Reasonable Limit?}

The most important general question to arise out of Videoflicks, viz. whether a province can enact Sunday closing legislation with no substantial exemptions to accommodate religious freedom and justify this failure as a reasonable limitation within section 1 , will, in all likelihood, remain unanswered. It is clear that the test required to justify the abrogation of a fundamental right is a very substantial one. ${ }^{25} \mathrm{It}$ is equally clear that the onus of discharging that substantial burden is upon the party seeking to uphold the validity of impugned legislation. ${ }^{26}$ Yet, in Videoflicks, counsel for the Attorney-General of Ontario presented no evidence on this issue beyond referring to the fact that Sunday was a common day of closing in many countries. One can hardly dispute the Ontario C.A.'s conclusion that these bare analogies were insufficient. The persisting question is whether or not Ontario is now estopped from introducing additional evidence before the Supreme Court on the issue of

23. See the judgment of Laycraft, J.A., as he then was, in R. v. Big M Drug Mart Ltd. (1984) 7 C.R.R. 92 at 99-103 (Alta. C.A.). The issue was expressly left open by the S.C.C. on appeal: see $\operatorname{Big} M$, supra, n. 1 at 95 .

24. See, for example, the Shops Act, 1950 (U.K.) supra, n. 22, s. 53(3).

25. Sẹe Public Service Alliance of Canada v. The Queen (1984), 9 C.R.R. 248 (F.C.T.D.) per Reed J. at 271.

26. Federal Republic of Germany v. Rauca (1983) 41 O.R. (2d) 225 (Ont. C.A.). The more common ways of discharging the burden of justification under $s$. 1 were enumerated by Houlden, J.A. in R. v. Bryant (1984) 11 C.R.R. 219, 240 (Ont. C.A.), as follows: (1) an examination of the rationale and purpose of the legislation, (2) comparable legislation in other free and democratic societies, including judicial interpretation of such legislation, (3) international conventions and agreements on the same or similar subject matter, (4) judicial decisions of other Canadian courts on the same legislation, (5) the calling of oral evidence, and (6) the argument of counsel. 
reasonableness. ${ }^{27}$ While it has been emphasized that courts must be flexible in their approach to Charter cases, particularly concerning evidence of relevant facts, ${ }^{28}$ it is doubtful that the Supreme Court of Canada would extend the principle of flexibility to include such a radical departure from traditional appellate rules concerning fresh evidence. Indeed, the observations of Estey, J. in The Law Society of Upper Canada v. Skapinker do not lend support: ${ }^{29}$

... As experience accumulates, the law profession and the courts will develop staridards and practices which will enable the parties to demonstrate their position under s.1 and the courts to decide issues arising under that provision. May it only be said here, in the cause of being helpful to those who come forward in similar proceedings, that the record on the $s .1$ issue was indeed minimal, and without more, would have made it difficult for a court to determine the issue as to whether a reasonable limit on a prescribed right had been demonstrably justified ...

Given that the Supreme Court recently has again stressed the importance of building an adequate evidentiary record to support legislation under s. $1,{ }^{30}$ it is unlikely that the Videoflicks appeals will definitively resolve the question of provincial legislative parameters in the area of Sunday closings. Leaving this aside for the moment, it is still relevant to assess the grounds upon which Ontario and other provinces might justify uniform closing legislation absent religious exemptions as a "reasonable limit" upon the Charter guarantee of religious freedom.

In the Big $M$ case Dickson C.J.C. set out a sequential analysis to assess a governmental objective versus the means employed to achieve it in order to determine whether or not a restraint is a "reasonable limit" within s. 1 of the Charter: first, the "governmental interest or policy objective" in the impugned legislation must be ascertained; second, a judicial assessment must be made to determine whether this objective is of sufficient importance to override a Charter right; third, and only in the event the governmental interest is so recognized, a "proportionality test" must be applied to determine whether the means chosen to achieve the interest are reasonable in the sense of impairing as little as possible the Charter right in question. ${ }^{31}$ It is important to note that in this sequential analysis of objective vs. means employed, the sufficiency of importance of a governmental objective is assessed independently of the legislative means adopted to achieve it. Only after an objective has been adjudged as sufficiently significant to override a Charter right is an assessment conducted of the adopted means and the degree of infringement it entails vis-a-vis alternative means available and the degree of infringement they entail. Thus, where no reasonable alternative means is

27. Under s. 67 of the Supreme Court Act, R.S.C. 1970, c. S-19, as am., the court may allow a party to introduce new evidence in the S.C.C. The general principle is that leave will not be granted if the evidence was not introduced at trial and the party, by reasonable diligence could have discovered such evidence: Gootson v. The King, [1948] 4 D.L.R. 33 (S.C.C.). See also: Dormuth v. Untereiner [1964] S.C.R. 123.

28. This is purportedly to ensure that the competing interests of government action and individual rights are fully canvassed: $R$. v. Bryant, supra, n. 26 at 225 .

29. [1984] 1 S.C.R. 357 at 384.

30. Singh et al. v. Minister of Employment and Immigration (1985) 58 N.R. 1 at 67 per Wilson J., with Dickson C.J.C. and Lamer J. concurring.

31. Big $M$, supra, n, 1 at 116 . In delivering her reasons for judgment Wilson, $J$. concurred with the Chief Justice's comments on the sequence of the inquiry contemplated by s. 1 : id., at 121. 
available to accomplish the governmental objective in question the sequential analysis dictates that the legislation will be of full force and effect under section 1 .

A careful reading of the Videoflicks case suggests that the primary governmental objective advanced in the Retail Business Holidays Act is not unlike that historically asserted in support of Sunday closing laws, viz. that public convenience, order and health require a uniform day of rest. ${ }^{32}$ While this objective is undoubtedly defensible in the abstract, is it of sufficient importance to warrant overriding a constitutionally protected guarantee of religious freedom? Although the Supreme Court has not provided any guidance to date concerning the appropriate principles to be applied in determining the question of "sufficient significance", the following comments of the Chief Justice in Big $M$ of fer resolute support for the view that the provincial objective in uniform closing legislation may, in some cases, achieve the requisite degree of importance: ${ }^{33}$

The other more plausible argument is that everyone accepts the need and value of a universal day of rest from all work, business and labour. . . . I accept the secular justification for a day of rest in a Canadian context and the reasonableness of a day of rest has been clearly enunciated by the courts in the United States of America. . . .

Assuming that Ontario's objective in the Retail Business Holidays Act is of sufficient importance, can the objective be achieved by other reasonable means which infringe to some lesser extent upon religious freedom? American courts have dealt with this question at length ${ }^{34}$ and the alternative legislative schemes which have been considered commonly fall into three categories: (1) legislation providing for one day's work stoppage in seven, leaving the choice of day to the individual; (2) legislation providing for a common day of rest on some day held sacred by no religion; and (3) legislation providing for Sunday work stoppage with a conscientious sabbatarian exception. While these alternatives are not exhaustive, they do illustrate the "all or nothing" approach to means that may be necessary if one accepts the validity of a uniform closing objective.

The provincial purpose in uniform closing laws is quite distinct from day-of-rest legislation. The interest is not with a one-in-seven day of rest but with a common day of rest ${ }^{35}$ and the difference is between providing periodic physical rest on an individual basis and providing it within an atmosphere of familial and community repose. The one-in-seven day of rest alternative also presents significant enforcement problems on account of the difficulty of detecting violations.

32. The exceptions created in the Act support the alleged purpose of Sunday as a day of rest and bear a rational relationship to it. The major exception in s. 3(4) is not antithetical and provides a residual base of convenience where a "corner-store" is closed for business on the Saturday preceding its Sunday opening.

33. Big $M$, supra n. 1 at 116-117.

34. McGowan et al. v. Maryland, 366 U.S. 420 (1961); Two Guys from Harrison-Allentown, Inc. v. McGinley et al., 366 U.S. 582 (1961); Braunfeld et al. v. Brown et al., supra n. 10; Gallagher et al. v. Crown Kosher Super Market, supra n. 10.

35. In Ontario, as in the other provicnes, there are wholly separate requirements imposing upon employers and employees maximum hours of daily and weekly work: see Employment Standards Act, R.S.O. 1980, c. 137, s. 17. See also Industrial Standards Act, R.S.O. 1980 , c. 216. 
The second alternative of choosing a common day of rest on some day held sacred by no religion necessitates the designation of a common day of rest that an overwhelming percentage of the population would not select of their own accord. The impolicy of this approach was underscored by Frankfurter, J. in McGowan et al. v. Maryland in the following words: ${ }^{36}$
... For to many who do not regard it sacramentally, Sunday is nevertheless a day of special, long-established associations, whose particular temper makes it a haven that no other day could provide. The will of a majority of the community, reflected in the legislative process during scores of years, presumably prefers to take its leisure on Sun- day. The spirit of any people expresses in goodly measure the heritage which links it to its past. Disruption of this heritage by a regulation which, like the unnatural labors of Claudius' shipwrights, does not divide the Sunday from the week, might prove a measure ill-designed to secure the desirable community repose for which Sunday legisla- tion is designed.

Assessing the conscientious Sabbatarian exception alternative is more complex. It is noteworthy that many jurisdictions, absent constitutional compulsion, have opted for this approach in enacting Sunday closing legislation. ${ }^{37}$ Yet if the legitimate governmental interest is to provide for periodic physical rest for individuals within an atmosphere of familial and community repose, the efficacy of this alternative to accomplish the purpose can also be questioned. To the degree that conscientious Sabbatarians conduct normal business within the community the atmosphere of familial and community repose is disquieted. Legislative experience elsewhere serves to illustrate the practical difficulties inherent in attempts to effect exceptions for persons conscientiously observing another day as the sabbath. ${ }^{38}$ As these exceptions are generally contingent upon having to close for business on a day other than Sunday, enforcement difficulties are increased as well. ${ }^{39}$ In addition, Sabbatarian exemptions may have the disadvantage of placing the beneficiaries in a privileged position. Although the Ontario C.A. refused to speculate on this possibility, a simple illustration will suffice to demonstrate that some potential for the recipient's competitive advantage does exist. If the Orthodox Jewish faith, for example, requires its adherents to refrain from shopping on Saturdays, ${ }^{40}$ a Sabbatarian exception allows the Orthodox Jewish merchant to solicit the custom of all consumers, including Orthodox Jewish consumers, on six days per week. The Christian merchant, on the other hand, can solicit the custom of all consumers, including Orthodox Jewish

36. Supra n. 34 at 507.

37. Variations include requiring a "conscientious" belief and observance of another day, membership in a "religious" society observing another day, registration requiring a statutory declaration of conscientious objection, etc. For the American precedents see Appendix Il to the opinion of Frankfurter, J. in McGowan et al. v. Maryland, supra $\mathrm{n}$. 34. For an English precedent see the Shops Act 1950, 14 Geo. 6 c. 28 as am.

38. Id. The English precedent is, perhaps, the most extravagant example.

39. This argument loses much of its potency in specific application to the Retail Business Holidays Act because there was no evidence in the Videoflicks case of any enforceable difficulties brought about by the limited exception already afforded to small businesses which close on Saturdays: see s. 3(4).

40. The Orthodox Jewish faith requires the closing of places of business and the abstention from work, shopping, etc. from nightfall each Friday until nightfall each Saturday: see the assertion of the appellant, Nortown Foods Ltd., in Videoflicks, supra n. 3 at 412 . See also Gallagher et alv. Crown Kosher Super Market, supra, n 10 at 618. 
consumers, on only five days per week because on his permissible sixth day of business Orthodox Jewish consumers are prevented by the tenets of their faith from shopping. Does this not, albeit to a limited degree, make it "more difficult and more costly to practice [the Christian] religion" within the Ontario C.A.'s broad test for infringement of the Charter guarantee of religious freedom? ${ }^{41}$

Considerations analogous to the foregoing led the United States Supreme Court to refuse to label as "unreasonable" a legislative finding that these suggested alternatives were unsatisfactory to accomplish the legislative purpose in Sunday closing laws ${ }^{42}$ Of course, the approach mandated by s. 1 of the Charter is quite different in that it places a positive evidentiary burden upon government to establish that the impugned legislation is reasonable. It is suggested, however, that with the supporting evidentiary base a province might well succeed although, as discussed above, this is not likely to occur in the Videoflicks appeals.

\section{A Selective Application?}

In the event that the Supreme Court of Canada finds either that the provincial objective in uniform closing legislation is of unsufficient importance to override Charter rights, or that, although the provincial objective is of sufficient importance, the means chosen to achieve it in the Retail Business Holidays Act is unreasonable, an important question remains, viz. what effect does the failure to provide any substantial religious exemptions have upon the operative provisions of the legislation? The Videoflicks appellants, other than Nortown Foods Ltd., asserted that it should render the provisions of no force or effect by reason of s. 52(1) of the Constitution Act, $1982 . .^{43}$ The Ontario C.A. rejected this assertion and interpreted the section 2(a) guarantee as limited to protecting only those persons who could prove a genuinely held religious belief.

The Supreme Court of Canada, on the other hand, in Big M, recognized an "absolute" dimension inherent in the Charter guarantee of religious freedom and held that the purpose of the Lord's Day Act, viz. to prevent profanation of the Christian Sabbath, clearly violated it. Big $M$ establishes the irrelevance of an accused having to prove an actual

41. An additional argument of reverse economic advantage was recognized by Warren, C.J. of the U.S.S.C.: "If he [the Orthodox Jewish storekeeper] opens on Saturday, he is subjected to very fierce competition indeed from Christian shopkeepers, whereas on Sunday, supposing he closes on Saturday, he has an absolutely free run and no competition from. Christian shopkeepers at all. That is a tremendous advantage. In many districts he will be the only trader with a shop open in that district": Braunfeld et al. v. Brown et al., supra n 10 at 609 , n. 6 .

42. McGowen et al. v. Maryland, supra n. 34 at 449-452; Two Guys from Harrison-Allentown, Inc. v. McGinley et al., supra, n. 34 at 598; Braunfeld et al v. Brown et al., supra n. 10 at 608; Gallagher et al. v. Crown Kosher Super market, supra n. 10 at 630.

43. S. 52(1) provides: "The Constitution of Canada is the supreme law of Canada, and any law that is inconsistent with the provisions of the Constitution is, to the extent of the inconsistency, of no force or ef fect." 
violation of his religious freedom in these circumstances. As stated by Dickson, C.J.C.: ${ }^{44}$

... A law which itself infringes religious freedom is, by that reason alone, inconsistent with s. 2(a) of the Charter and it matters not whether the accused is a Christian, Jew, Muslim, Hindu, Buddhist, atheist, agnostic or whether an individual or corporation. It is the nature of the law, not the status of the accused, that is in issue. . . .

But the Chief Justice did not restrict a declaration of unconstitutionality exclusively to those cases where the legislation in question has an of fensive purpose vis-a-vis the Charter. To the contrary, later in the judgment he expressly acknowledged that either an unconstitutional purpose or an unconstitutional ef fect could invalidate legislation. ${ }^{45} \mathrm{He}$ went on to state “. . . [I]f a law with a valid purpose interferes by its impact with rights or freedoms, a litigant could still argue the effects of the legislation as a means to defeat its applicability and possibly its validity." "46 [Emphasis added.] The effects-oriented analytic approach to Charter cases asserted by Madame Justice Wilson of fers yet stronger support. Her approach invalidated the Lord's Day Act not because its purpose violated the Charter guarantee of religious freedom but, rather, because "... the effect of the Lord's Day Act is to compel the observance of Sunday as a day of rest ..." and this limitation upon religious freedom could not be justified under s. 1.47 [Emphasis added.]

If the "effect" upon Charter rights is sufficient in some cases to invalidate legislation notwithstanding that the legislation has an unobjectionable purpose vis-a-vis the Charter, what kind of "effect" is required? The only answer that appears to have emerged thus far is that a declaration of unconstitutionality will result whenever, without justification under section 1, the effect of the legislation is to limit a Charter right to the point of denying it. Just as in the case of an unconstitutional purpose vis-a-vis the Charter, this would also violate the "absolute" dimension inherent in the guaranteed rights and freedoms. Thus, in Singh et al. $v$. Minister of Employment and Immigration, ${ }^{48}$ the three judges of the Supreme Court of Canada who decided the case on the basis of the Charter held that the procedures for the determination of refugee status claims in s. 71(1) of the Immigration Act violated the principles of fundamental justice guaranteed by s. 7 of the Charter in failing to provide for an oral hearing. After determining that the procedures could not be justified as a "reasonable limit" under s. 1, they declared the section constitutionally invalid under s. 52(1) of the Constitution Act, 1982.49 Similarly, in $\operatorname{Re}$ Southam Inc. and The Queen (No. 1), ${ }^{50}$ the Ontario

44. Big $M$, supran. 1 at 95 . The Supreme Court of Canada also acknowledged the potential applicability of a "personal" dimension where ". . . the legislation under review had a secular purpose and the accused was claiming that it interfered with his religious freedom, land in these circumstances] the status of the accused and the nature of his belief might be relevant ...": id. at 96 .

45. Id. at 105 .

46. Id. at 106 .

47. Id. at 122

48. Supran. 30 at 27-74.

49. As stated by Wilson, J. ". . . [I]t seems to me that $\mathrm{s} .71(1)$ is precisely the type of express provision which prevents the courts from reading the principles of natural justice into a statutory scheme for the adjudication of the rights of individuals": id. at 47.

50. (1983), 41 O.R. (2d) 113 (Ont. C.A.). 
Court of Appeal upheld a declaration that s. 12(1) of the Juvenile Delinquents Act, which effectively required that the trial of all juveniles be held in camera, was unconstitutional because of the nature of its effect. ${ }^{51}$

In determining the effect of the Retail Business Holidays Act it is important to note that the Act can only be marginally distinguished from legislation containing no religious exemptions whatever. While it is true that, pursuant to s. 3(4), some percentage of Orthodox Jewish practicants could open their businesses on Sundays providing they meet the maximum square footage, maximum employee and Saturday closing requirements, it is fortuitous insofar as the option is equally available to all small corner-store-type businesses and is independent of any requirement of religious belief. Such an exception, as noted by the Ont. C.A., in Videoflicks, does not, for example, even fortuitously accommodate a Mohammedan small retailer. ${ }^{52}$

Judicial clarification is now required from the Supreme Court to determine where the dividing line rests between the "absolute" and "personal" dimensions of the Charter guarantee of religious freedom. Although the issue was not expressly addressed by the Ontario C.A., the Videoflicks appeals present the S.C.C. with an opportunity to decide whether a valid distinction can really be drawn between legislation, like the Lord's Day Act, the very purpose of which is to favour the practices of one or more religions and legislation with a valid secular purpose, like the Retail Business Holidays Act, which effectively achieves, albeit indirectly, the same result by an unjustified failure to provide substantial exemptions to accommodate religious freedom as it has now been broadly defined.

\section{CONCLUSION}

As a result of the Ontario Court of Appeal decision in Videoflicks and the subsequent Supreme Court of Canada decision in Big $M$ it is now clear that provincial legislatures have the authority to enact Sunday closing laws. What is still unclear is the extent to which these laws absent religious exemptions can be generally ef fective.

While the Videoflicks appeals will necessarily decide whether the Province of Ontario can justify the operative provisions of the Retail Business Holidays Act as a "reasonable limit" within s. 1 of the Charter, unless the Supreme Court permits additional evidence, it is unlikely that the decision will delimit other provincial attempts to legislate Sunday closing laws with no religious exemptions. The ultimate disposition of the appeals will, however, provide definitive guidance on what effect should be afforded to extant Sunday closing legislation without substantial religious exemptions where a province is unable to discharge the onus of establishing the impugned legislation as a "reasonable limit" upon the Charter guarantee of religious freedom.

51. Id. at 134. See also: Re Ontario Film \& Video Appreciation Society and Ontario Board of Censors (1984), 45 O.R. (2d) 80 (Ont. C.A.), leave to appeal to the S.C.C. granted (Ritchie, Dicken, Estey, Mclntyre and Wilson J.J.) April 4, 1984.

52. Friday is the traditional sabbath observed by Muslims. 